\title{
UPAYA GURU DALAM MENINGKATKAN KEMAMPUAN MENGENAL ANGKA MELALUI MEDIA GAMBAR (FLASHCARDS) PADA TAMAN KANAK-KANAK ANSYAL DESA TOLOWATA KECAMATAN AMBALAWI
}

\author{
Lis Sukartin, Muslim \\ Email: liskurwati123@gmail.com
}

\section{ABSTRAK}

Penelitian ini menggunakan jenis penelitian kualitatif. Dengan menggunakan metode deskriptif. Penelitian ini membahas tentang peningkatan kemampuan Mengenal Angka Melalui Media Gambar (Flashcards) Pada TK. Ansyal Desa Tolowata Kecamatan Ambalawi. Penelitian ini dilatar belakangi oleh: kemampuan anak dalam mengenal angka bahwa guru sering menggunakan media gambar dalam mengembangkan berbagai kemampuan anak terutama dalam mengenal angka, dan anak juga senang menggunakan media gambar. Dari hal-hal demikian maka penulis tertarik untuk mengkaji secara mendalam mengenai peningkatan kemampuan mengenal angka melalui media gambar (flashcards) pada TK. Ansyal Desa Tolowata Kecamatan Ambalawi. Permasalahan yang ingin dikaji dalam penelitian ini adalah: 1) Upaya guru dalam meningkatkan kemampuan mengenal angka melalui media gambar (flashcards). 2) Faktor penghambat dan faktor pendukung dalam meningkatkan kemampuan mengenal angka melalui media gambar (Flashcards) pada Taman Kanak-Kanak Ansyal Desa Tolowata Kecamatan Ambalawi. Adapun hasil dari penelitian ini; guru dapat memperkenalkan angka dengan menggunakan media gambar kepada anak-anak, mampu memberikan semangat dan motivasi belajar kepada anak-anak, sehingga anak-anak merasa senang dan bahagia ketika di ajarkan.

Kata Kunci : Mengenal Angka Melalui Media Gambar (Flashcards)

\section{PENDAHULUAN}

Anak usia dini adalah anak yang sedang menjalani suatu proses perkembangan dengan pesat dan fundamental bagi kehidupan 
selanjutnya. Anak usia dini berada pada rentang usia 0-6 tahun. Pada masa ini proses pertumbuhan dan perkembangan dalam berbagai sedang mengalami masa yang cepat dalam rentang perkembangan hidup manusia. Proses pembelajaran sebagai bentuk perlakuan yang diberikan pada anak harus memperhatikan karakteristik yang dimiliki setiap tahapan perkembangan anak. Pendidikan pada anak usia dini adalah suatu proses pembinaan tumbuh kembang anak sejak lahir sampai umur 6 tahun, yang dilakukan secara menyeluruh, mencakup semua aspek perkembangan dengan memberikan stimulasi terhadap perkembangan jasmani dan rohani agar anak dapat tumbuh dan berkembang secara optimal. ${ }^{1}$

Pendidikan pada anakusia dinipada dasarnya meliputi seluruhupaya dan tindakan yang dilakukan oleh pendidik dan orang tua dalam proses perawatan, pengasuhan dan pendidikan pada anak dengan lingkungan dimana anak dapat mengeksplorasi pengalaman yang memberikan kesempatan padanya untuk mengetahui dan memahami pengalaman belajar yang diperolehnya dari lingkungan, melalui cara mengamati, meniru dan bereksperimen yang berlangsung secara berulang-ulang dan melibatkan seluruh potensi dan kecerdasan anak.

Salah satu kompetensi yang harus dimiliki oleh peserta didik adalah mampu mengikuti pendidikan selanjutnya dengan kesiapan yang optimal sesuai dengan tuntutan yang berkembang dalam masyarakat. Kemampuan dasar yang dikembangkan di Taman Kanak meliputi kemampuan bahasa, fisik/motorik, seni dan kemampuan kognitif. Pengembangan kemampuan kognitif bertujuan meningkatkan kemampuan berpikir anak. Pada kemampuan kognitif tersebut, anak diharapkan dapat mengenal konsep sains dan matematika sederhana.

Masa kanak-kanak merupakan masa di mana anak-anak mengalami perkembangan yang sangat pesat, mereka tumbuh, berkembang, berkreasi dan akan berdampak luar biasa serta menjadi pengalaman yang sangat berharga ketika anak mulai menjalani kehidupannya, maka dari itu pada usia tersebut para ahli menyebutkan bahwa anak mengalami masa keemasan (golden age) karena pada masa ini anak mengalami pertumbuhan dan perkembangan yang sangat pesat.

\footnotetext{
${ }^{1}$ Sudarna, PAUD Berkarakter: Melejitnya Kepribadian Anak Secara Utuh, (Yogyakarta : Genius Publisher, 2014), hal.1.
} 
Selain itu pada usia ini merupakan masa peka bagi anak, di mana anak mulai sensitif untuk menerima berbagai upaya perkembangan seluruh potensi anak. Masa peka adalah masa di mana terjadinya kematangan fungsi-fungsi fisik dan psikis yang siap merespon stimulasi yang diberikan oleh lingkungannya. ${ }^{2}$

Taman Kanak-Kanak Ansyal Desa Tolowata Kecamatan Ambalawi merupakan salah satu Taman Kanak-kanak Negeri di Desa Tolowata, dimana sebagian besar masyarakat Desa Tolowata yang memiliki anak-anak usia dini menyekolahkan anak-anak mereka pada Taman Kanak-Kanak Ansyal tersebut. Kegiatan belajar mengajar pada Taman Kanak-Kanak Ansyal biasa dilakukan mulai dari hari senin sampai hari sabtu. Yang mana kegiatan belajar mengajar (KBM) pada Taman Kanak-Kanak Absyal guru-gurunya mengajarkan anak - anak dengan metode belajar sambil bermain dan selalu menggunakan media, baik itu media apasaja. Berdasarkan hasil observasi yang dilakukan oleh peneliti terdahulu pada anak di Taman Kanak-Kanak Ansyal, masih ada anak-anak pada Taman Kanak-Kanak Ansyal lebih cenderung mengingat pelajaran dengan melihat gambar ataupun sambil bergambar. Disini peneliti dapat melihat kebiasaan-kebiasaan yang dilakukan oleh anak-anak pada Taman Kanak-Kanak Ansyal bila sedang belajar guru menjelaskan di depan, masih ada anak yang tidak memperhatikan apa yang disampaikan oleh gurunya di depan kelas, setelah didekati anak tersebut sedang asik mengambar atau bermain dengan gambar-gambar yang ada.

Bila berkaitan dengan kemampuan anak dalam mengenal angka bahwa guru sering menggunakan media gambar dalam mengembangkan berbagai kemampuan anak terutama dalam mengenal angka, dan anak juga senang menggunakan media gambar, sehingga peneliti ingin meneliti apakah media gambar berpengaruh terhadap peningkatan kemampuan mengenal angka.

Berdasarkan permasalahan yang terjadi di Taman Kanak-Kanak Ansyal Desa Tolowata Kecamatan Ambalawi, penulis tertarik untuk meneliti secara langsung pemanfaatan media gambar (flascard) sebagai salah satu cara meningkatkan kemampuan mengenal konsep bilangan anakPAUD dan dapat memperbaiki kondisi pembelajaran yang terjadi di PAUD Ansyal. Media ini dianggap mampu memecahkan masalah diatas

${ }^{2} I b i d, \ldots . . . . h a l .2$.

Jurnal Pelangi Jurnal pemikiran dan penelitian pendidikan Islam anak Usia Dini 
karena dalam proses pembelajaran, alat bantu atau media tidak hanya dapat memperlancar proses komunikasi akan tetapi dapat merangsang siswa untuk merespon dengan baik segala pesan yang disampaikan.

Penggunaan media pembelajaran selain dapat memberi rangsangan bagi siswa untuk terjadinya proses belajar, media pembelajaran juga memiliki peranan penting dalam menunjang kualitas proses belajar mengajar. Media pembelajaran merupakan segala sesuatu yang digunakan untuk menyalurkan pesan serta dapat merangsang pikiran, perasaan, perhatian, dan kemauan si belajar sehingga dapat mendorong terjadinya proses belajar yang disengaja, bertujuan, dan terkendali.

Atas dasar alur pemikiran di atas, maka penulis tertarik untuk mengkaji secara mendalam mengenai kemampuan anak. Dan penelitian tersebut tertuang pada skripsi yang berjudul Peningkatkan kemampuan Mengenal Angka Melalui Media Gambar (Flashcards) Pada TK. Ansyal Desa Tolowata Kecamatan Ambalawi.

\section{TINJAUAN TENTANG GURU}

\section{Pengertian Guru}

Guruadalah sosokyangdigugu dan ditiru. Diguguartinyadiindahkan atau dipercayai. Sedangkan ditiru artinya dicontoh atau diikuti. Belajar adalah tugas utama peserta didik. Para ahli mengemukakan pengertian belajar dapat didefinisikan sebagai tingkah laku yang ditimbulkan atau diubah melalui latihan atau pengalaman. ${ }^{3}$

Guru dalam pandangan Islam merupakan pengganti kedudukan Rasulullah Saw, dalam menyampaikan petunjuk dan kebenaran kepada umat manusia serta mengajarkan kepada mereka apa-apa yang bermanfaat bagi kehidupan mereka di dunia dan akhirat. Allah SWT dan Rasulullah Saw, sangat menaruh perhatian terhadap keberadaan para guru yang senantiasa mempelajari dan mengajarkan ilmu pengetahuan serta ditinggikan derajat mereka oleh-Nya. Allah SWT berfirman dalam Q.S. Al-Mujadilah: 11 yang berbunyi4:

\footnotetext{
${ }^{3}$ Sugiharto, Peran Guru Dalam Pembelajaran, (Jakarta : PT. Rineka Cipta, 2013), hal.21

${ }^{4}$ Departemen Agama Islam, Al-Qur'an Tajwid dan Terjemahanya, (Mushaf Al-Kamil), hal.544
} 


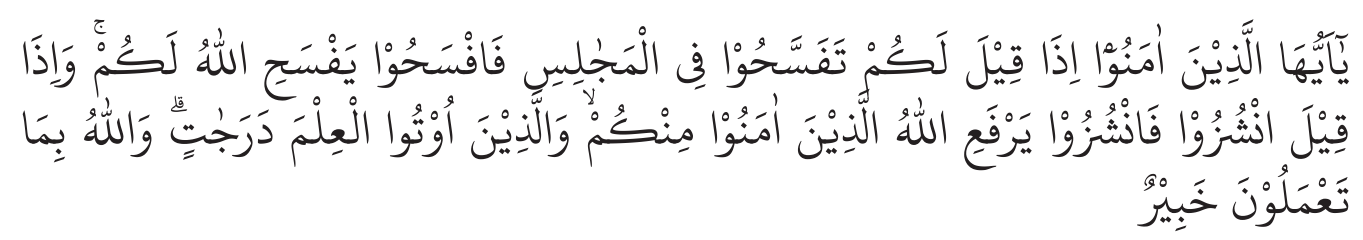

Artinya: Hai orang-orang beriman apabila kamu dikatakan kepadamu: «Berlapang-lapanglah dalam majlis», Maka lapangkanlah niscaya Allah akan memberi kelapangan untukmu. dan apabila dikatakan: "Berdirilah kamu», Maka berdirilah, niscaya Allah akan meninggikan orang-orang yang beriman di antaramu dan orang-orang yang diberi ilmu pengetahuan beberapa derajat. dan Allah Maha mengetahui apa yang kamu kerjakan.

Guru memegang peranan strategis terutama dalam upaya membentuk watak melalui pengembangan kepribadian dan nilai-nilai yang diinginkan. Dari dimensi tersebut, peranan guru sulit digantikan oleh yang lain. Dipandang dari dimensi pembelajaran, peranan guru dalam masyarakat Indonesia tetap dominan sekalipun teknologi yang dapat dimanfaatkan dalam proses pembelajaran berkembang amat cepat.

Kinerja guru pada dasarnya menyangkut seluruh aktifitas yang dilakukannya dalam mengemban amanat dan tanggung jawabnya dalam mendidik, mengajar, membimbing, mengarahkan, dan memandu siswa dalam mencapai tingkat kedewasaan atau kematangannya. Seorang pendidik yang profesional tentunya akan memiliki kebanggaan yang besar terhadap pekerjaan yang ia geluti dan kemampuan yang dimilikinya, yang mendasari keputusannya dalam pekerjaan profesionalnya tersebut.

Profesionalitas seorang guru tentunya dituntut oleh beberapa pihak yang selalu mendukung keberadaan guru. Seorang pendidik atau guru agama yang profesional adalah pendidik yang memiliki suatu kemampuan dan keahlian dalam bidang kependidikan sehingga mampu untuk melakukan tugas, peran, dan fungsinya sebagai pendidik dengan kemampuan yang maksimal. ${ }^{5}$

\section{Peran dan Fungsi Guru}

Peran dan fungsi guru sebagai berikut :

a. Guru Sebagai Pendidik

Guru adalah pendidik, yang menjadi tokoh, panutan dan identifikasi

${ }^{5}$ Mukhtar, Desain Pembelajaran Pendidikan agama Islam, (Jakarta: CV misaka galiza, 2003), hal.85.

Jurnal Pelangi Jurnal pemikiran dan penelitian pendidikan Islam anak Usia Dini 
bagi para peserta didik, dan lingkungannya. Oleh karena itu, guru harus memiliki standar kualitas tertentu, yang mencakup tanggung jawab, wibawa, mandiri dan disiplin. ${ }^{6}$ Peran guru sebagai pendidik (nurturer) berkaitan dengan meningkatkan pertumbuhan dan perkembangan anak untuk memperoleh pengalaman-pengalaman lebih lanjut seperti penggunaan kesehatan jasmani, bebas dari orang tua, dan orang dewasa yang lain, moralitas tanggungjawab kemasyarakatan, pengetahuan dan keterampilan dasar, persiapan untuk perkawinan dan hidup berkeluarga, pemilihan jabatan, dan hal-hal yang bersifat personal dan spiritual. ${ }^{7}$

b. Guru Sebagai Pengajar

Peranan guru sebagai pengajar dan pembimbing dalam kegiatan belajar peserta didik dipengaruhi oleh berbagai factor, seperti motivasi, kematangan, hubungan peserta didik dengan guru, kemampuan verbal, tingkat kebebasan, rasa aman dan keterampilan guru dalam berkomunikasi. Jika factor-faktor di atas dipenuhi, maka melalui pembelajaran peserta didik dapat belajar dengan baik. Guru harus berusaha membuat sesuatu menjadi jelas bagi peserta didik dan terampil dalam memecahkan masalah. ${ }^{8}$

c. Guru Sebagai Pembimbing

Guru dapat diibaratkan sebagai pembimbing perjalanan, yang berdasarkan pengetahuan dan pengalamannya bertanggung jawab atas kelancaran perjalanan itu. Dalam hal ini, istilah perjalanan tidak hanya menyangkut fisik tetapi juga perjalanan mental, emosional, kreatifitas, moral dan spiritual yang lebih dalam dan kompleks.

Sebagai pembimbing perjalanan guru memerlukan kompetensi yang tinggi untuk melaksanakan empat hal berikut:

1) Guru harus merencanakan tujuan dan mengidentifikasi kompetensi yang hendak dicapai.

2) Guru harus melihat keterlibatan peserta didik dalam pembelajaran, dan yang paling penting bahwa peserta didik melaksanakan kegiatan belajar itu tidak hanya secara jasmaniah, tetapi mereka harus terlibat secara psikologis.

\footnotetext{
${ }^{6}$ Sugiharto, Peran Guru. .hal.23.

${ }^{7}$ Ibid, .......hal.24

${ }^{8}$ Ibid,......hal.25
} 
3) Guru harus memaknai kegiatan belajar.

4) Guru harus melaksanakan penilaian.

5) Guru Sebagai Pemimpin. ${ }^{9}$

e. Guru Sebagai Pengelola Pembelajaran

Guru harus mampu menguasai berbagai metode pembelajaran. Selain itu, guru juga dituntut untuk selalu menambah pengetahuan dan keterampilan agar supaya pengetahuan dan keterampilan yang dirnilikinya tidak ketinggalan jaman. ${ }^{10}$

\section{KAJIAN TENTANG BILANGAN DAN ANGKA}

\section{Pengertian Bilangan dan Angka}

Bilangan adalah suatu konsep matematika yang digunakan untuk pencacahan dan pengukuran. Bilangan bersifat abstrak. Bilangan memberikan keterangan mengenai banyaknya sesuatu. ${ }^{11}$ mengatakan bahwa bilangan adalah satuan dalam sistem matematika yang dapat dioperasionalkan secara matematik. Bilangan adalah suatu konsep matematika yang sangat penting untuk dikuasai oleh anak karena menjadi dasar bagi penguasaan konsep matematika selanjutnya di jenjang pendidikan formal berikutnya.

Bilangan dan angka merupakan dua hal yang berbeda. Bilangan mewakili banyaknya suatu benda. Simbol ataupun lambang yang digunakan untuk mewakili suatu bilangan disebut sebagai lambang bilangan atau angka. Angka adalah suatu lambang tertulis sebagai anggota dari suatu sistem penghitungan dan pengukuran. ${ }^{12}$

Dari beberapa definisi di atas disimpulkan bahwa bilangan dan angka adalah hal yang berbeda. Bilangan adalah konsep matematika yang digunakan untuk pencacahan dan pengukuran yang dapat dioperasionalkan secara matematik. Angka adalah lambang dari bilangan tersebut dan merupakan konsep matematika yang digunakan dalam pencacahan dan pengukuran.

\footnotetext{
${ }^{9}$ Ibid,.......hal.26

${ }^{10} \mathrm{Ibid}, \ldots . .$. hal. 27

${ }^{11}$ Negoro \& Harahap, Ensiklopedia Matematika, ( Bogor: Ghalia Pustaka , 2014), hal.32.

${ }^{12}$ Longman. Dictionary of Contemporary English. Suffolk: Richard Clay, 1987), 710
} 


\section{Pengertian Kemampuan Mengenal Angka AUD}

Permendiknas Nomor 58 Tahun 2009 memuat standar Tingkat Pencapaian Perkembangan lingkup perkembangan kognitif mengenai konsep bilangan dan angka. Standar tersebut menyatakan bahwa anak usia 5-6 tahun, yang termasuk kelompok B di dalam kegiatan di Taman Kanak-kanak, dapat menyebutkan angka 1-10. Pola perkembangan kognitif anak usia 5-6 tahun adalah adanya kemampuan dalam mengurutkan obyek, mulai meggunakan angka, jumlah dan panjang. ${ }^{13}$

Secara umum konsep matematika pada anak usia dini meliputi hal-hal sebagai berikut:

a. Memilih, membandingkan dan mengurutkan, misalnya memilih balok yang pendek diteruskan ke yang lebih panjang sehingga membentuk urutan dari yang paling pendek ke yang paling panjang.

b. Klasifikasi, yaitu mengelompokkan benda-benda ke dalam beberapa kelompok berdasarkan ukuran dan bentuknya.

c. Menghitung, yaitu menghubungkan antara konsep benda dengan konsep bilangan.

d. Angka, yaitu simbol dari kuantitas. Anak dapat menghubungkan antara banyaknya benda dengan simbol angka.

e. Pengukuran, yaitu anak dapat mengukur ukuran suatu benda dengan berbagai cara, baik dengan ukuran non standar (kaki, depa dan jengkal) maupun standar (dengan penggaris atau meteran).

f. Geometri, yaitu mengenal bentuk, luas, volume dan area.

g. Membuat grafik, misalnya guru membagi kartu merah, hijau dan kuning untuk anak yang suka apel, mangga dan pisang. Guru menyuruh anak untuk menempelkan pada papan tulis yang telah diberi sumbu datar $(X)$ dan tegak $(Y)$ sehingga akan tampak gambaran tentang banyaknya anak yang suka buah-buahan tersebut.

h. Pola, yaitu membentuk pola, misalnya guru memberi angka 1,3,6 lalu anak melanjutkan dengan suatu pola tertentu bisa 1,3,6 atau 3,6,1.

i. Problem solving, yaitu kemampuan memecahkan persoalan sederhana yang melibatkan bilangan dan operasi bilangan. ${ }^{14}$

\footnotetext{
${ }^{13}$ Yuliani Nurani Sujiono. Konsep Dasar Pendidikan Anak Usia Dini.Jakarta: PT Indeks, 2011),67

${ }^{14}$ Slamet Suyanto. Konsep Dasar Pendidikan Usia Dini. (Yogyakarta: UNY, 2003), hal.176177.
} 


\section{MEDIA PEMBELAJARAN}

\section{Pengertian Media Pembelajaran}

Media adalah alat saluran komunikasi. Kata media berasal dari bahasa latin yang merupakan bentuk jamak dari medium. Secara harafiah, media berarti perantara, yaitu perantara antara sumber pesan (source) dan penerima pesan (receiver). ${ }^{15}$ Media adalah sutu metode untuk memberikan informasi. Berdasarkan beberapa definisi di atas dapat disimpulkan bahwa media adalah alat perantara untuk penyampaian informasi antara dua pihak yaitu sumber pesan dan penerima pesan. ${ }^{16}$

\section{Karakteristik Media Pembelajaran}

Tidak semua media merupakan media pembelajaran, tergantung pada pesan dan isi yang akan disampaikan. Dalam media pembelajaran, pesan yang disampaikan adalah pendidikan. ${ }^{17}$ Media memiliki fungsi sebagai pembawa informasi dari sumber (guru) menuju penerima (siswa). Media adalah alat untuk membantu siswa dalam menerima dan mengolah informasi guna mencapai tujuan pembelajaran. ${ }^{18}$

Ada beberapa ciriumum yang harus dipunyai oleh media pembelajaran. Pertama, media pembelajaran harus dapat dindera, yaitu diraba, dilihat, didengar dan diamati dengan komponen utama indera penglihatan dan pendengaran. Kedua, media pembelajaran merupakan bentuk komunikasi antara guru dan murid. Ketiga, media pembelajaran merupakan alat bantu utama dalam mengajar di dalam kelas dan di luar kelas. Keempat, media pembelajaran erat kaitannya dengan metode mengajar. ${ }^{19}$

Media harus mempunyai syarat yang harus dipenuhi agar bisa dibuat sebagai media pembelajaran, yaitu:

a. Rasional, yaitu sesuai dengan akal dan dapat dipikirkan oleh penggunanya.

b. Ilmiah, yaitu sesuai dengan kaidah-kaidah ilmu pengetahuan.

c. Ekonomis, yaitu sesuai dengan kemampuan pembiayaan sehingga

${ }^{15}$ Dina Indriana. Ragam Alat Bantu Media Pembelajaran. Yogyakarta: Diva Press, 2011), hal.13.

${ }^{16}$ Longman. Dictionary of Contemporary , ............hal.650.

${ }^{17}$ Wina Sanjaya. Media Komunikasi Pembelajaran. Jakarta: Kencana Prenada Group, 2012), hal.58.

${ }^{18}$ Daryanto. Media Pembelajaran. Bandung: Sarana Tutorial Nurani Sejahtera, 2012),8

${ }^{19}$ Indriana. Ragam Alat Bantu, 53-54

Jurnal Pelang̉i Jurnal pemikiran dan penelitian pendidikan Islam anak Usia Dini 
lebih hemat dan efisien.

d. Praktis, yaitu dapat digunakan dalam kondisi praktis di sekolah dan bersifat sederhana. ${ }^{20}$

\section{Bentuk-Bentuk Media Pembelajaran}

Pada dasarnya media pembelajaran mempunyai lima bentuk dasar yaitu suara, gambar, grafik, garis dan gerakan. Berdasarkan bentuk informasi yang digunakan, media pembelajaran dibagi dalam lima macam, yaitu:

a. Media visual diam

Merupakan media yang dapat diterima oleh indera penglihatan yang tidak bergerak, misalnya foto, kartu.

b. Media visual bergerak

Merupakan media yang dapat diterima oleh indera penglihatan yang bergerak, misalnya film tanpa suara.

c. Media audio

Merupakan media yang dapat diterima dengan indera pendengaran, misalnya tape, audio CD.

d. Media audiovisual diam

Merupakan media yang dapat diterima dengan indera penglihatan maupun pendengaran, tetapi tidak bergerak, misalnya sound slide atau film strip bersuara.

e. Media audiovisual gerak

Merupakan media yang dapat diterima oleh indera pendengaran dan penglihatan dan dapat bergerak, misalnya film bersuara, televisi, dan lain-lain. ${ }^{21}$

Media dapat disajikan dalam bentuk penglihatan langsung, proyeksi optik, proyeksi elektronik atau telekomunikasi. Menurut jenisnya, media pembelajaran dibagi menjadi dua. Pertama, aspek bentuk fisik, yang terdiri dari media elektronik dan nonelektronik. Kedua, aspek pancaindera, yang mencakup media audio, media visual, media audiovisual dan media grafis.

Wina Sanjaya juga membagi media berdasarkan kemampuan jangkauannya. Pertama, media yang mempunyai daya liput dan serentak

\footnotetext{
${ }^{20}$ Ibid., 56

${ }^{21}$ Ibid, ,......hal.58.
} 
seperti radio dan televisi. Kedua, media yang daya liputnya terbatas oleh ruang dan waktu seperti film atau video. Berdasarkan bentuknya, media pembelajaran dapat berupa media cetak (printed media), media pameran (displayed media), media yang diproyeksikan (projected media), rekaman audio (audiotape recording), gambar bergerak (motion pictute) dan media berbasis computer (computer based media). ${ }^{22}$ Dengan menganalisis media melalui bentuk dan cara penyajian, mengklasifikasikan media pembelajaran sebagai berikut:
a. grafis, bahan cetak, dan gambar diam
b. media proyeksi diam
c. media audio
d. media gambar hidup/film
e. media televisi
f. multimedia ${ }^{23}$

Daryanto membagi multimedia menjadi dua kategori, yaitu multimedia linier dan multimedia interaktif. Multimedia linier adalah suatu multi media yang tidak dilengkapi alat pengontrol yang dioperasikan oleh pengguna sehingga media ini berjalan secara berurutan, seperti televisi dan film. Multimedia interaktif sudah dilengkapi dengan alat pengontrol sehingga pengguna dapat memilih proses selanjutnya yang dikehendaki. ${ }^{24}$

\section{MEDIA GAMBAR}

Media grafis dalam konteks media pembelajaran, adalah media yang mengkomunikasikan data dan fakta, gagasan serta ide-ide melalui gambar dan kata-kata. Menurut Wina Sanjaya, yang termasuk media grafis adalah bagan, poster, karikatur, grafik serta gambar dan foto. Gambar adalah hasil coretan tangan manusia baik secara manual atau memakai alat modern, sedangkan foto merupakan hasil dari fotografi. ${ }^{25}$

Media gambar yang digunakan dalam penelitian ini adalah media visual diam yang disajikan dalam bentuk penglihatan langsung. Media

\footnotetext{
${ }^{22}$ Wina Sanjaya. Media Komunikasi,

${ }^{23}$ Indriana. Ragam Alat Bantu,.............hal.56.

${ }^{24}$ Daryanto. Media Pembelajaran, .............hal.53.

${ }^{25}$ Wina Sanjaya. Media Komunikasi, .............hal.157-166.
} 
digambarkan tidak terlalu rumit agar lebih mudah untuk diingat oleh anak. Media gambar merupakan metode yang lebih konkret dibanding media simbol visual atau media verbal. ${ }^{26}$

Gambar merupakan media yang umum dipakai untuk berbagai macam kegiatan pembelajaran, Gambar yang baik bukan hanya dapat menyampaikan saja tetapi dapat digunakan untuk melatih ketrampilan berpikir serta dapat mengembangkan kemampuan imajinasi anak. Jika diberikan sebuah gambar, anak dapat menceritakan kejadian yang nampak pada gambar sesuai dengan persepsinya.

Penggunaan media gambar sebagai sebuah media pembelajaran mempunyai beberapa manfaat dan kelebihan.

a. Gambar dapat menghilangkan verbalisme.

Dengan menggunakan gambar dalam pembelajaran maka persoalan yang dibicarakan akan lebih konkret dibandingkan dengan hanya menggunakan bahasa verbal.

b. Gambar dapat mengatasi batasan ruang dan waktu.

Dengan menggunakan gambar dapat mengatasi obyek yang tidak mungkin dibawa ke ruang kelas, karena terlalu besar seperti membawa gajah ke dalam kelas atau terlalu kecil untuk membawa kuman, atau karena letaknya yang terlalu jauh. Gambar dapat mengabadikan peristiwa penting masa lalu, seperti peristiwaperistiwa sejarah masa lalu.

c. Gambar merupakan media yang mudah diperoleh, harganya murah serta penggunaannya tidak memerlukan peralatan khusus.

Di samping kelebihan di atas, penggunaan media gambar dalam pembelajaran juga mempunyai keterbatasan sebagai berikut:

a. Gambar merupakan media visual yang hanya mengendalikan indera penglihatan, oleh sebab itu tidak memberikan informasi yang mendalam tentang suatu hal. Media gambar hanya dapat digunakan oleh orang yang mempunyai indera penglihatan yang normal dan sehat.

b. Tidak seluruh bahan pelajaran dapat disajikan dengan media ini. Bahan pelajaran mengenai proses yang mengadung gerakangerakan tertentu kurang efektif disajikan dengan media gambar. 
Agar gambar dapat berfungsi sebagai media pembelajaran dalam kegitan belajar mengajar, Wina Sanjaya mengingatkan beberapa pertimbangan yang harus diperhatikan, diantaranya:

a. Gambar sebagai media pembelajaran sebaiknya dibuat atau disusun tidak hanya mempertimbangkan unsur seni saja, tetapi lebih penting adalah kesesuaian dengan tujuan yang hendak dicapai. Gambar yang indah belum tentu cocok digunakan sebagai media pembelajaran.

b. Gambar yang dibuat harus menggambarkan benda aslinya, jangan ditambah dan dikurangi, walaupun dari sudut seni dianggap kurang artistik.

c. Gambar harus mampu menunjukkan bagian-bagian yang dianggap penting.

Gambar yang tidak jelas dapat mengakibatkan kesalahan persepsi anak. Anak yang belum tahu besarnya kapal terbang tidak akan mampu menangkap bagaimana besarnya benda tersebut hanya dengan melihat gambarnya saja. Oleh sebab itu, untuk menggambarkan perbandingan perlu diambil unsur lain sebagai informasi.

d. Gambar yang dibuat hendaklah gambar yang hidup, yaitu gambar yang menunjukkan aktivitas. Hal ini sangat penting terutama untuk mengembangkan imajinasi anak.

e. Gambar hendaknya dibuat dengan sederhana dan tidak terlalu kompleks sehingga dapat membingungkan anak. ${ }^{27}$

\section{MEDIA FLASH CARD}

\section{Pengertian Media}

Media adalah perantara sumber pesan dengan penerima pesan. ${ }^{28}$ Azhar Rasyad mengemukakan bahwa media merupakan segala sesuatu yang dapat dipakai untuk mengantarkan pesan. ${ }^{29}$ Sedangkan Nurbiana menyatakan bahwa media adalah segala bentuk alat komunikasi yang

\footnotetext{
${ }^{27}$ Wina Sanjaya. Media Komunikasi, hal.168

${ }^{28}$ Badru Zaman, Media dan Sumber Belajar TK. (Jakarta: Universitas Terbuka, 2009), hal.13.

${ }^{29}$ Azhar Rasyad. Media Pembelajaran. (Jakarta: Raja Grafindo Persada , 2011), hal.117.
} 
dapat digunakan untuk menyampaikan pesan atau informasi dari sumber yang bertujuan agar dapat merangsang pikiran, perasaan, minat, dan perhatian penerima pesan atau informasi tersebut. ${ }^{30}$

Media pembelajaran adalah wahana dari pesan oleh sumber pesan atau guru dan ingin diteruskan kepada penerima pesan yaitu anak. ${ }^{31}$ Pesan yang disampaikan adalah isi pembelajaran dalam bentuk tema atau topik pembelajaran dengan tujuan agar terjadi proses belajar dalam diri anak. Media pembelajaran selalu terdiri dari dua unsur, yaitu unsur peralatan atau perangkat keras (hardware) dan unsur pesan yang dibawanya yang disebut massage atau software. ${ }^{32}$

Menurut Haryanto pemanfaatan media pembelajaran dapat mempertinggi proses belajar anak. Hal tersebut karena media dapat menarik perhatian anak sehingga menumbuhkan motivasi belajar, bahan pelajaran akan lebih jelas maknanya sehingga lebih mudah dipahami dan dikuasai, metode lebih bervariasi dibandingkan hanya dengan komunikasi verbal antara guru dan anak. Selain itu anak juga akan lebih banyak melakukan kegiatan belajar karena tidak hanya mendengarkan guru saja. ${ }^{33}$

Menurut Syaiful Bahri Djamarah dan Aswan Zain proses belajar mengajar dengan bantuan media akan mempertinggi kegiatan belajar anak dalam tenggang waktu yang cukup lama. Hal ini berarti bahwa kegiatan belajaranak dengan bantuan media akan menghasilkan proses dan hasil belajar yang lebih baik dibandingkan tanpa bantuan media. Dalam penggunaan media pembelajaran juga harus memperhatikan dan mempertimbangkan tujuan agar hasil yang diperoleh maksimal. ${ }^{34}$

Dari berbagai pendapat di atas, maka dapat disimpulkan bahwa media adalah segala sesuatu yang dapat dipakai untuk mengantarkan pesan. Dalam kegiatan pembelajaran, media dapat disebut media pembelajaran sebagai perantara sumber pesan (guru) dengan penerima pesan (anak) yang berisikan bahan atau isi pelajaran dengan tema tertentu. Penggunaan media pembelajaran dapat mempertinggi proses belajar anak karena media dapat menarik perhatian anak, membuat

\footnotetext{
${ }^{30}$ Nurbiana Dhieni, Metode Pengembangan Bahasa. (Jakarta: Universitas Terbuka, 2008), hal.8.

${ }^{31}$ Badru Zaman, Media dan Sumber, hal.13.

${ }^{32}$ Ibid., 14

${ }^{33}$ Haryanto. Evaluasi Media Instruksional. (Yogyakarta: UNY, 2000), 18

${ }^{34}$ Syaiful Strategi Belajar Mengajar. (Jakarta: Rineka Cipta, 2006), 26
} 
bahan pelajaran lebih jelas, metode lebih bervariasi, serta anak akan lebih banyak melakukan kegiatan belajar (tidak hanya mendengarkan guru saja).

\section{Pengertian Media Flash Card}

Flash card adalah media pembelajaran visual yang berisi kata-kata, gambar, atau kombinasinya. ${ }^{35}$ Menurut Dina Indriana flash card adalah media pembelajaran dalam bentuk kartu bergambar yang berukuran 25 $\mathrm{cm} \times 30 \mathrm{~cm}$. Gambar yang ditampilkan dapat berupa gambar tangan atau foto yang sudah ada kemudian ditempelkan pada lembaranlembaran kartu. ${ }^{36}$

Menurut Azhar Arsyad flash card adalah kartu yang berisikan gambargambar (benda, binatang, dan sebagainya) yang dapat digunakan untuk melatih anak mengeja dan memperkaya kosa kata. Media ini menjadi petunjuk dan rangsangan bagi anak untuk memberikan respon yang digunakan. Flash card ini biasanya berukuran $8 \mathrm{~cm} \times 12 \mathrm{~cm}$ atau dapat disesuaikan dengan besar kecilnya kelas yang dihadapi ${ }^{37}$

Dari berbagai pendapat di atas dapat disimpulkan bahwa flash card adalah salah satu media visual dengan ukuran $8 \mathrm{~cm} \times 12 \mathrm{~cm}$ atau dapat disesuaikan dengan kebutuhan yang berisikan gambar-gambar tangan atau foto yang sudah ada.

\section{Kelebihan Media Flash Card}

Dina Indriana menyebutkan beberapa kelebihan media flash card yaitu mudah dibawa karena ukurannya dan praktis dalam pembuatan dan penggunaan. Selain itu, media flash card mudah diingat karena gambar yang disajikan berwarna-warni serta berisikan huruf atau angka yang mudah dan menarik sehingga merangsang otak untuk lebih lama mengingat pesan yang ada dalam media tersebut. ${ }^{38}$

\footnotetext{
${ }^{35}$ Basuki Media Pengajaran. (Jakarta: PDK, Direktorat Jenderal Pendidikan Tinggi, Proyek Tenaga Kependidikan, 1991), hal.30.

${ }^{36}$ Indriana. Ragam Alat Bantu,.............hal.68.

${ }^{37}$ Azhar Rasyad. Media Pembelajaran,.............hal.120.

${ }^{38}$ Indriana. Ragam Alat Bantu,.............hal.69.
}

Jurnal Pelang̉i Jurnal pemikiran dan penelitian pendidikan Islam anak Usia Dini 


\section{METODE PENELITIAN}

Penelitian ini menggunakan jenis penelitian kualitatif. ${ }^{39}$ Adapun Tujuan penelitian kualitatif adalah penelitian untuk membuat gambaran ataupun paparan secara sistematis, faktual dan akurat mengenai faktafakta serta hubungannya antara fenomena yang dimiliki. Sedangkan pendapat lain yang mengatakan bahwa penelitian kualitatif adalah suatu penelitian yang ditujukan untuk mendeskripsikan dan menganalisis fenomena, peristiwa, kepercayaan, persepsi, pemikiran orang secara individual maupun kelompok.

Sumber Data dan Tehnik Pengumpulan Data adalah: 1) Data Primer. Data Primer yaitu data yang diperolah langsung dari subyek penelitian dengan menggunakan pengukuran atau alat pengambilan data langsung pada subyek sebagai informasi yang dicari. Sumber data dalam penelitian ini adalah kepala sekolah, guru, orang tua siswa dan siswa di Taman Kanak-Kanak Ansyal Desa Tolowata. 2) Data Sekunder. Data Sekunder yaitu data yang diperoleh lewat pihak lain, tidak langsung diperoleh oleh peneliti dari subyek penelitiannya. Seperti dari buku-buku ilmiah, internet, jurnal, skripsi lain dan data Taman Kanak-Kanak Ansyal Desa Tolowata. Teknik Pengumpulan Data dalam penelitian ini: 1) Metode Observasi. 2) Metode wawancara. dan 3) Metode dokumentasi. ${ }^{40}$

Instrumen dalam penelitian ini penelitian menggunakan instrument yang berupa pedoman wawancara dan instrument yang kedua yang digunakan peneliti untuk mengumpulkan data adalah pedoman observasi, yaitu pedoman yang mengarahkan penelitian tentang prosedur, tahapan dan urutan dalam melakukan pengambilan data tentang peningkatkan kemampuan mengenal angka melalui media gambar (flashcards) pada Taman Kanak-Kanak Ansyal Desa Tolowata Kecamatan Ambalawi.

Teknik Analisis Data. Setelah semua data terkumpul, maka langkah selanjutnya adalah pengelolahan dan analisa data. Yang dimaksud dengan analisis data ialah proses mencari dan menyusun secara sistematis data yang diperoleh dari hasil wawancara, catatan lapangan, dan

\footnotetext{
${ }^{39}$ Suharsimi Arikunto, Prosedur Penelitian Suatu Pendekatan Praktik, ( Jakarta: Rineka Cipta 1987), hal.45.

${ }^{40} \mathrm{Ibid}$, .......hal.46.
} 
dokumentasi, dengan cara mengorganisasikan data ke dalam kategori, menjabarkannya kedalam unit-unit, melakukan sintesa, menyusunnya ke dalam pola, memilih mana yang penting dan akan dipelajari, serta membuat kesimpulan sehingga mudah dipahami oleh dirinya sendiri atau orang lain. Teknik analisis data yang akan digunakan dalam penelitian ini adalah Analisis kualitatif. Metode analisis akan di lakukan dengan tiga cara yaitu : 1) Reduksi Data, 2) Penyajian Data, dan 3) Penarikan Kesimpulan. Pengujian keabsahan data. Dalam menguji keabsahan data ini peneliti menggunakan triangulasi data adalah teknik pengumpulan data yang bersifat menggabungkan dari berbagai teknik pengumpulan data dan sumber data yang telah ada. Bila peneliti melakukan pengumpulan data dengan triangulasi, maka sebenarnya peneliti mengumpulkan data yang sekaligus menguji kredibilitas data, yaitu mengecek kredibilitas data dengan berbagai teknik pengumpulan data dan berbagai sumber data. ${ }^{41}$

\section{HASIL PENELITIAN}

\section{Upaya guru dalam meningkatkan kemampuan Mengenal Angka Melalui Media Gambar (Flashcards) Pada Taman Kanak-Kanak Ansyal Desa Tolowata Kecamatan Ambalawi.}

Guru dalam proses belajar mengajar di sekolah memiliki peran sebagai pengajar, pendidik, dan pembimbing yang menyampaikan sejumlah materi pelajaran kepada siswa. Untuk itu guru harus dituntut untuk membekali diri, terutama menguasai materi pelajaran, metode mengajar, dan tekhnik evaluasi, disamping itu guru harus memiliki komukasi yang baik terhadap siswanya, supaya materi pelajaran dapat diterima dengan baik oleh siswa.

Dari hasil temuan penelitian dilapangan bahwa upaya guru dalam meningkatkan kemampuan mengenal angka melalui media gambar (flashcards) pada Taman Kanak-Kanak Ansyal Desa Tolowata Kecamatan Ambalawi, peneliti melakukan wawancara dengan Yuyun Yuniarsih, mengatakan yakni sebagai berikut:

Upaya dalam meningkatkan kemampuan mengenal angka melalui media gambar (flashcards) pada siswa, disini kami berusaha memahami,

${ }^{41}$ Sugiyono, Metode Penelitian Kuantitatif Kualitatif dan RED, Bandung: Alfabeta, 2010), hal.67.

Jurnal Pelang̉i Jurnal pemikiran dan penelitian pendidikan Islam anak Usia Dini 
mengetahui karakter anak tersebut, kami selalu mengunakan berbagai macam metode yang menyenangkan, bermain sambil belajar, dan berbagai macam media, disini kami mengunakan media gambar (flashcard) angka, dimana banyak cara dengan mengunakan media ini, disini adalah dengan bermain jemur-jemuran angka, kami menyiapkan tali rapia berserta penjepi jemuran, kemudian flashcard angka 1-10 di acak di meja anak, dalam kelas B ada 18 siswa di bagi 2 kelompok tiap kelompok 9 siswa, mendapatkan 10 flashcard dari angka 1-10, sebelum permainan dimulai, anak-anak lombah duduk cantik, duduk manis, duduk sopan. ${ }^{42}$ Kemudian yang paling duduk manis akan diberikan kesempatan pertama, lalu ibu guru menyebutkan ambil angka 2 yang seperti bebek. Dengan sigap anak pertama di tiap kelompok mencari angka 2 kemudian cepat-cepat di bawa kedepan untuk dijepitkan pada tali rapia di depan kelas, dan seakan-akan lagi berjemur, jika anak tersebut berhasil maka akan diberikan hadia berupa bintang. Hal tersebut terus berlangsung, yang sering keliru adalah angka 6 dan angka 9 anakanak sering terbalik dalam menjemur. Disini pernan guru seperti angka enam gendutnya dibawa, sedangkan angka 9 gendutnya diatas. Inilah upaya kami untuk meningkatkan kemampuan mengenal angka melalui media gambar (flashcards) pada siswa dan saya merasa lebih berhasil dibandingkan dengan belajar seperti biasa. ${ }^{43}$

Dari hasil temuan penelitian dilapangan bahwa upaya guru dalam meningkatkan kemampuan mengenal angka melalui media gambar (flashcards) pada Taman Kanak-Kanak Ansyal Desa Tolowata Kecamatan Ambalawi, peneliti melakukan wawancara dengan Rumaini, mengatakan yakni sebagai berikut:

Upaya kami dalam meningkatkan kemampuan mengenal angka dengan flashcard, membuat anak merasa nyaman dalam belajar, dengan bermacam-macam metode anak-anak akan lebih cepat memahami, mengerti apa yang diajarkan, lebih menarik karena ada media yang dijadikan alat pembelajaran. Contohnya dalam pembelajaran angka 1-10, kami menyiapkan kartu berupa gambar diatasnya dan angka di bawanya, kami berusaha untuk tetap mengajar dengan suasana

\footnotetext{
${ }^{42}$ Yuyun Yuniarsih, Wawancara, tgl 3 Oktober 2018

${ }^{43}$ Yuyun Yuniarsih, Wawancara, Tgl 4 Oktober 2018
} 
gembira, anak-anak kami bagi menjadi 2 kelompok masing-masing 9 anak, tiap kelompok kami bagikan 10 kartu yang masing-masing beda gambar. Kemudian ibu guru berdiri didepan kelas, mengatakan jika ada anak yang duduk manis, duduknya rapi akan di diberikan satu kartu yang bergambar Apel. Dalam kartu itu terlihat gambar sebuah Apel dan dibawa apel tersebut ada angka 1. Kemudian anak-anak dengan semangat dan cepat-cepat duduk manis, tenang dengan harapan kartu itu akan diberikan padanya. Kemudian ibu guru memangil salah satu anak pada tiap-tiap kelompok untuk maju, dan memberikan kartu gambar berangka (flashcard).

Kedua anak tersebut ibu guru memberikan gambar buah Apel dan tetapi yang satu hanya satu buah gambar dan dibawahnya ada angka 1 dan yang satunya ada dua buah gambar Apel dibawahnya ada angka 2, kemudian kartu (flashcard) itu di angkat mengarah pada teman-teman yang duduk kemudian kedua anak tersebut menyebutkan angka tersebut dan jumlah gambar apel tersebut, jika anak tersebut berhasil menyebutkan gambar dan angkat tersebut dengan benar maka dia pantas mendapatkan bintang. Hal tersebut terus berlangsung sampai kartu bergambar 1-10 habis di tangan ibu guru. Media ini sangat menyenangkan bagi anak-anak, semua semangat jika metode dan media ini kami mainkan dalam kelas. ${ }^{44}$

Dari hasil temuan penelitian dilapangan bahwa upaya guru dalam meningkatkan kemampuan mengenal angka melalui media gambar (flashcards) pada Taman Kanak-Kanak Ansyal Desa Tolowata Kecamatan Ambalawi, peneliti melakukan wawancara dengan Mardiana, mengatakan yakni sebagai berikut:

Kami sebagai guru mengharapkan anak-anak Taman Kanak-Kanak Ansyal Desa Tolowata ini bisa menjadi anak-anak yang cerdas, pintar, dan berhasil kelak, upaya kami sebagai guru agar anak ini tekun belajar, disini peran kami agar pelajaran ini menyenangkan, menarik dan tidak terbebankan bagi anak, disini banyak sekali metode yang kami terapkan dan banyak pula media yang sering kami gunakan, semuanya bervariasi dan selalu mengunakan metode belajar sambil bermain, karena bagi kami dengan bermain anak-anak akan lebih cepat memahami.

${ }^{44}$ Rumaini, Wawancara, Tgl 6 Oktober 2018

Jurnal Pelang̉i Jurnal pemikiran dan penelitian pendidikan Islam anak Usia Dini 
Dalam meningkatkan kemampuan mengenal angka melalui media gambar (flashcards) angka pada anak, ibu guru telah menulis angka dengan beberapa kartu lalu ditempelkan pada papan tulis, kemudian anak-anak kami buat menjadi dua kelompok, tiap kelompok berjumlah 9 anak, tiap anak di damping oleh 1 orang ibu guru, tiap kelompok kami berikan 10 (flashcards) angka 1-10, masing-masing anak mendapatkan 1 kartu dan tersisa 1 untuk ibu guru, lalu ibu di depan kelas dengan pengaris panjang dia menunjuk salah satu kartu diatas, jika ia menunjuk angka 1 maka anak-anak yang memegang angka satu mengangkat kartu mereka setinggi-tingginya. Sambil berkata angka satu seperti tiang listrik, selanjutnya angkat 2 anak-anak yang memegang angka 2 mengangkat kartu mereka setinggi-tingginya, sambil berkata angka 2 seperti bebek, selanjutnya 3 seperti burung, 4 seperti kursi, 5 seperti paman gendut, 6 seperti keong, 7 sepertu cangkul pak tani, 8 seperti kacamata, 9 seperti rang bungkuk sampai akhirnya angka 10 yang memegang ibu guru seperti tiang dan bola. Anak-anak sangat menyukai cara belajar seperti ini, menyenangkan, mengasikan. ${ }^{45}$

Dari hasil temuan penelitian dilapangan bahwa upaya guru dalam meningkatkan kemampuan mengenal angka melalui media gambar (flashcards) pada Taman Kanak-Kanak Ansyal Desa Tolowata Kecamatan Ambalawi, peneliti melakukan wawancara dengan Hairunisa, mengatakan yakni sebagai berikut:

Hasil wawancara dengan seorang Hairunisa. Beliau mengatakan, "upaya guru dalam meningkatkan kemampuan mengenal angka melalui media gambar (flashcards) pada Taman Kanak-Kanak Ansyal Desa Tolowata Kecamatan Ambalawi, langkah-langkah yang kami lakukan adalah penggunaan metode mengajar yang bervariasi, dalam proses pembelajaran di Taman Kanak-Kanak Ansyal kami sering menggunakan metode belajar sambil bermain, dimana metode ini sangat memotivasi, menyenangkan bagi anak-anak di Taman KanakKanak Seroja. Anak-anak akan senang belajar jika anak-anak itu di ajak bermain, dalam belajar mengenal angka dengan menggunakan kartu disini kami mengajak anak-anak agar dapat berbicara di depan teman ataupun di depan kelas. Dengan alat peraga berupa kartu dengan angka akan memudahkan anak untuk memahami apa yang dilihat.

${ }^{45}$ Mardiana, Wawancara, Tgl 6 Oktober 2018 
Di Taman Kanak-Kanak Ansyal kita berusaha agar anak-anak selalu senang, bahagia saat belajar. Disini kita guru akan berinteraksi untuk mendapatkan respon dari anak.

Dalam proses pembelajaran pengenalan huruf ataupun berhitung menggunakan media kartu, disini pihak sekolah menyediakan kartu angka yang ada gambarnya bergambar, anak-anak di berikan pertanyaan siapa yang mau mengambil salah satu kartu yang dipegang oleh Ibu, diantara beberapa anak ada anak yang agresip secepatnya lari ke depan kelas mengambil salah satu kartu yang dipegang oleh Ibu guru, kemudian anak itu memilih salah satu kartu yang di pegang oleh ibu, kemudian di perlihatkan kepada teman-teman sambil menyebut angka apa yang dipegang, jika ia memegang angak 1 , maka ibu guru akan memberi pertanyaan lagi, angka satu seperti apa ? dengan semangat anak-anak akan menjawab seperti tiang, begitupun selanjutnya, jika ada anak yang mengambil angka 8 lalu memperlihatkan kepada siswa lain maka anak-anak langsung saja menjawab seperti kaca mata dan jika anak yang menjawab atau yang mengambil kartu dengan semangat akan diberikan penghargaan berupa Bintang. Di Taman Kanak-Kanak Ansyal sering kami lakukan pembelajaran demikian karena menurut kami asik, dan anak-anak senang. ${ }^{46}$

\section{Dampak Pendukung dan dampak Penghambat dalam meningkatkan kemampuan Mengenal Angka Melalui Media Gambar (Flashcards) Pada Taman Kanak-Kanak Ansyal Desa Tolowata Kecamatan Ambalawi.}

\section{a. Dampak Pendukung}

Dalam setiap pembelajaran tidak akan terlepas dari faktor-faktor yang mendukung dan menghambatnya. Adapun beberapa faktor yang dapat menjadi pendukung dalam penggunaaan media gambar (Flas cards) adalah sebagai berikut :

Menurut Ibu Yuyun Yuniarsi sebagai berikut: Guru lebih cepat mengetahui, memahami karakter anak tersebut dimana materi angka 1-10 yang diajarkan dengan mengunakan media gambar (Flashcards) lebih terfokus ataupun terarah dan anak-anak merasa bertanggung jawab

${ }^{46}$ Hairunas, Wawancara, Tgl 5 Oktober 2018.

Jurnal Pelangi Jurnal pemikiran dan penelitian pendidikan Islam anak Usia Dini 
atas kartunya tersebut. Semua kegiatan atau kegiatan belajar mengajar (KBM) berlangsung sangat berkesan bagi anak tersebut, karena mereka dapat andil dalam kegiatan belajar tersebut. Dan dengan menggunakan media gambar (flashcards) angka, anak-anak lebih bersemangat dalam belajar, lebih cepat memahami angka dan berani tampil. ${ }^{47}$

Sedangkan menurut Ibu Rumaini sebagai salah satu guru di TK Ansyal adalah :

Dengan mengunakan media gambar (flashcards) angka, pengajaran akan lebih menarik perhatian anak sehingga dapat menumbuhkan motivasi belajar yang lebih besar, dan dengan media gambar (flashcards) angka akan jelas dan siswa akan lebih cepat mengenal angka dan tidak ingin cepat pulang. ${ }^{48}$

Demikian juga menurut Ibu Mardiana adalah sebagai berikut:

Pelajaran dengan metode belajar sambil bermain dengan mengunakan media gambar (flashcards) angka lebih menarik perhatian anak sehingga dapat menumbuhkan motivasi belajar, pelajaran yang dimaksud dapat tersampaikan terlihat antusias anakanak dalam pembelajaran dan anak-anak tidak ingin cepat pulang. ${ }^{49}$ Senada dengan diatas Ibu Hairunas juga mengatakan bahwa Dengan belajar sambil bermain anak-anak akan lebih semangat, termotivasi, lebih cepat memahami dan anak-anak akan berlomba-lomba untuk merai bintang karena sudah berani tampil di depan. ${ }^{50}$

\section{b. Dampak Penghambat}

Sedangkan ada beberapa faktor penghambat dalam penggunan media gambar (Flascards) Menurut Ibu Mardiana sebagai berikut :

Dengan belajar seperti ini memakan banyak waktu, repot menyedikan semuanya, belum lagi ada media gambar (Flashcards) angka ataupun kertas yang rusak", butuh waktu yang cukup untuk menyiapkan semuanya. ${ }^{51}$

\footnotetext{
${ }^{47}$ Yuyun Yuniarsih, Wawancara, Tgl 4 Oktober 2018

${ }^{48}$ Rumaini, Wawancara, Tgl 6 Oktober 2018

${ }^{49}$ Mardiana, Wawancara, Tgl 6 Oktober 2018

${ }^{50}$ Hairunas, Wawancara, Tgl 5 Oktober 2018

${ }^{51}$ Mardiana, Wawancara, Tgl 6 Oktober 2018
} 
Sedangkan menurut Ibu Rumaini sebagai salah satu guru di TK Ansyal adalah;

Guru khawatir bahwa akan terjadi kekacauan di dalam kelas. Pembelajaran dengan media gambar (Flashcards) angka ini membuat suasan kelas kacau, ada yang berlari-lari kesana kemari, ada yang ingin maju duluan, ada yang menangis karena mau kartu seperti apa yang diambil temannya. ${ }^{52}$ Dan Ibu Yuyun Yuniarsi juga mengatakan hal demikian bahwa, Taman Kanak-Kanak Ansyal Desa Tolowata Kecamatan Ambalawi cukup jauh jika harus kekota membeli media (Flashcards) angka yang dibutuhkan dalam pembelajaran, sulit menemukan gambar-gambar yang bagus dan berkulitas serta sesuai dengan materi pelajaran, dan tidak tersedianya dana khusus untuk menemukan atau mengadakan gambar-gambar yang diinginkan. ${ }^{53}$

\section{KESIMPULAN}

1. Upaya guru dalam meningkatkan kemampuan Mengenal Angka Melalui Media Gambar (Flashcards) Pada Taman Kanak-Kanak Ansyal Desa Tolowata Kecamatan Ambalawi.

$>$ Guru dapat mengajak anak-anak bermain jemur-jemuran, mengajak anak untuk menjepit angka yang diambil dan disebutkan.

$>$ Menempel angka di papan tulis sesuai dengan gambar yang ada.

$>$ Menyamakan angka dengan sesuatu, 1 seperti tiang, 2 seperti bebek, selanjutnya 3 seperti burung, 4 seperti kursi, 5 seperti paman gendut, 6 seperti keong, 7 sepertu cangkul pak tani, 8 seperti kacamata, 9 seperti orang bungkuk sampai akhirnya angka 10 yang memegang ibu guru seperti tiang dan bola.

2. Dampak Pendukung dan Dampak Penghambat dalam meningkatkan kemampuan Mengenal Angka Melalui Media Gambar (Flashcards) Pada Taman Kanak-Kanak Ansyal Desa Tolowata Kecamatan Ambalawi.

a. Pendukung

\footnotetext{
${ }^{52}$ Rumaini, Wawancara, Tgl 6 Oktober 2018

${ }^{53}$ Yuyun Yuniarsih, Wawancara, Tgl 4 Oktober 2018
}

Jurnal Pelangỉ Jurnal pemikiran dan penelitian pendidikan Islam anak Usia Dini 
> Guru lebih cepat mengetahui, memahami karakter anak.

$>$ Menimbulkan kegairahan belajar, semangat dan termotivasi.

$>$ Adanya interaksi yang baik antara guru dan siswa .

$>$ Anak-anak cepat memahami apa yang diajarkan.

$>$ Anak-anak berani aktif, dan berani tampil.

$>$ Biar Jelas angka yang dimaksud

b. Penghambat

$>$ Memakan banyak waktu.

> Guru khawatir bahwa akan terjadi kekacauan dikelas.

> Tidak tersedianya dana khusus untuk menemukan atau mengadakan gambar-gambar yang diinginkan.

\section{REFERENSI}

Ades, Sanjaya, 2011, Model-model Pembelajaran, Jakarta: Bui Aksara. Arikunto, Suharsimi, 1987, Prosedur Penelitian Suatu Pendekatan Praktik, Jakarta: Rineka Cipta.

Badru Zaman, dkk, 2009, Media dan Sumber Balajar, Jakarta: Universitas Terbuka.

Basuki, Wibawa dan Faridah Mukti, 2001, Media Pengajaran, Bandung: CV Maulana.

Djamarah, 2002, Strategi Belajar Mengajar, Jakarta : Rineka Cipta. Hadi, Sutrisno, 1992, Metodologi Research Jilid I, Yogyakarta: Andi Offset. Hamzah B. Uno, 2010, Teori Motivasi dan Pengukurannya Analisis di Bidang Pendidikan, Jakarta: Bumi Aksara.

Hastuti, Sri, 1996, Strategi Belajar Mengajar Bahasa Indonesia, Jakarta: Departemen Pendidikan dan Kebudayaan Direktorat Jenderal Pendidikan Dasar dan Menengah Bagian Proyek Penataran Guru SLTP Setara D-III.

Kayvan, Umy, 2009, Permainan Kreatif untuk Mencerdaskan Anak. Jakarta : Media Kita.

Metodologi Research Jilid II, 2000, Yogyakarta: Andi Offset.

Nurani, A.T, 2004, Pengaruh Kualitas Perkawinan, Pengasuhan Anak Dan Kecerdasan Emosonal Terhadap Belajar Anak, Bogor: Fakultas Pertanian, Institu Pertanian Bogor. 
Nurani, Yuliani, 2012, Konsep Dasar Pendidikan Anak Usia Dini, Jakarta: PT Indeks.

Oemar, Hamalik, 2010, Proses Belajar Mengajar.

Poerwadarminta, 2007, Kamus Umum Bahasa Indonesi, Jakarta: PN Balai Pustaka.

Retno, Pudjiati, 2013, Bermain Bagi AUD, Jakarta: Direktorat Pembinaan Pendidikan Anak Usia Dini.

Sardiman, 2014, Interaksi dan Motivasi Belajar Mengajar, Jakarta: Raja Grafindo Persada.

Sudarna, 2014, PAUD Berkarakter, Melejitnya Kepribadian Anak Secara Utuh, Cetakan 1 Yogyakarta: Genius Publisher.

Sudaryanti, 2006, Pengenalan Matematika Anak Usia Dini, Yogyakarta: Fakultas Ilmu Pendidikan Universitas Negeri Yogyakarta.

Sugiyono, 2010, Metode Penelitian Kuantitatif Kualitatifdan RED, Bandung: Alfabeta.

Suryabrata, Sumadi, 1988, Metodologi Penelitian, Jakarta: PT. Radja Grafindo Persada.

Tadkirotun, Mudfiroh, 2012, Pengembangan Kecerdasan Majemuk, Tangeran: Universitas Terbuka.

Thoifuri, 2008, Menjadi Guru Inisiator, Semarang: Rasail Media Group Cet 1.

Tim PKP PG PAUD, 2018, Panduan Pemantapan Kemampuan Profesion, Jakarta: Universitas Terbuka.

Wardani IGAK, dkk. 2008, Penelitian Tindakan Kelas, Jakarta: Universitas Terbuka.

Zukhaira, 2010, Pembuatan dan Penggunaan Media Gambar dan Kartu Kata untuk pengajaran Bahasa Arab Madrasah Btiaiyah, Semarang: Universitas Negeri Semarang. 